\title{
İmam Hatip Okullarında Görev Yapan Öğretmenlerin Ahlaki Kişilik Özellikleri ve Örgütsel Vatandaşlık Davranışları Arasındaki İlişki*
}

\author{
Ali BİRİNCi ${ }^{* *}$
}

\author{
Bayramali NAZIROĞLU***
}

\begin{abstract}
Atıf/Cite as: Birinci, Ali-Nazıroğlu, Bayramali. “İmam Hatip Okullarında Görev Yapan Öğretmenlerin Ahlaki Kişilik Özellikleri ve Örgütsel Vatandaşlık Davranışları Arasındaki İlişki". Recep Tayyip Erdoğan Üniversitesi İlahiyat Fakültesi Dergisi 20 (2021), 382-406.
\end{abstract}

Öz: Bu çalışmada, imam hatip okullarında görev yapan öğretmenlerin ahlaki kişilik özellikleri ile örgütsel vatandaşlık davranışları arasındaki ilişki incelenmektedir. Betimsel nitelikteki ilişkisel tarama modelinde olan bu araştırmanın çalışma evreni Türkiye' deki yedi coğrafi bölgeyi temsilen İstatistiki Bölge Birimleri Sınıflandırmasına (IBBS) göre 12 bölgeden alınan 26 ilde 20202021 eğitim-öğretim yılında imam hatip lisesi ve ortaokulunda görev yapmakta olan öğretmenlerden oluşmaktadır. Araştırmanın örneklemini, çalışma evreninden tabakalı örnekleme yöntemiyle yansız olarak seçilmiş 3741 öğretmen oluşturmaktadır. Verilerin analizinde betimsel istatistikler ve korelasyon analizleri kullanılmıştır. Araştırmada öğretmenlerin ahlaki kişilik özellikleri ile örgütsel vatandaşlık davranışları arasında orta düzeyde, pozitif yönde anlamlı bir ilişki olduğu tespit edilmiştir $(r=0,537 ; \mathrm{p}<0,001)$.

Anahtar Sözcükler: Din Eğitimi, Ahlaki Kişilik, Örgütsel Davranış, Örgütsel Vatandaşlık Davranışı, İmam - Hatip Okulları, Öğretmen.

* Bu çalışma Recep Tayyip Erdoğan Üniversitesi Lisansüstü Eğitim Enstitüsü'nde Doç. Dr. Bayramali NAZIROĞLU danışmanlığında Ali BİRINCİ tarafından hazırlanan doktora tezinden üretilmiştir.

** Doktora Öğr. , Recep Tayyip Erdoğan Üniversitesi, Rize, Türkiye, ali_birinci171@erdogan.edu.tr, ORCID: www.orcid.org/0000-0003-2958-644X

*** Doç. Dr., Recep Tayyip Erdoğan Üniversitesi, Rize, Türkiye, bayramali.naziroğlu@erdogan.edu.tr, ORCID: www.orcid.org/0000-0003-2091-614X 


\title{
The Relationship Between Moral Personality Traits and Organizational Citizenship Behaviors of Teachers in Imam Hatip Schools
}

\begin{abstract}
The purpose of this study is to examine the relationship between moral personality traits and organizational citizenship behaviors of teachers working in imam hatip schools. The target population of this research, which is in descriptive relational scanning model, consists of teachers working in imam hatip high schools and secondary schools in 26 provinces from 12 regions in the NUTS classification representing seven geographical regions in Turkey in the 2020-2021 academic year. The sample of the study consists of 3741 teachers who were selected randomly from the target population with stratified sampling method. Descriptive statistics and correlation analyzes were used in the analysis of the data. It was determined that there were moderate, positive and significant relationships between teachers' moral personality traits and organizational citizenship behaviors ( $\mathrm{r}=0.537 ; \mathrm{p}<0,001)$.
\end{abstract}

Keywords: Religious Education, Moral Personality, Organizational Behavior, Organizational Citizenship Behavior, Imam - Hatip Schools, Teacher.

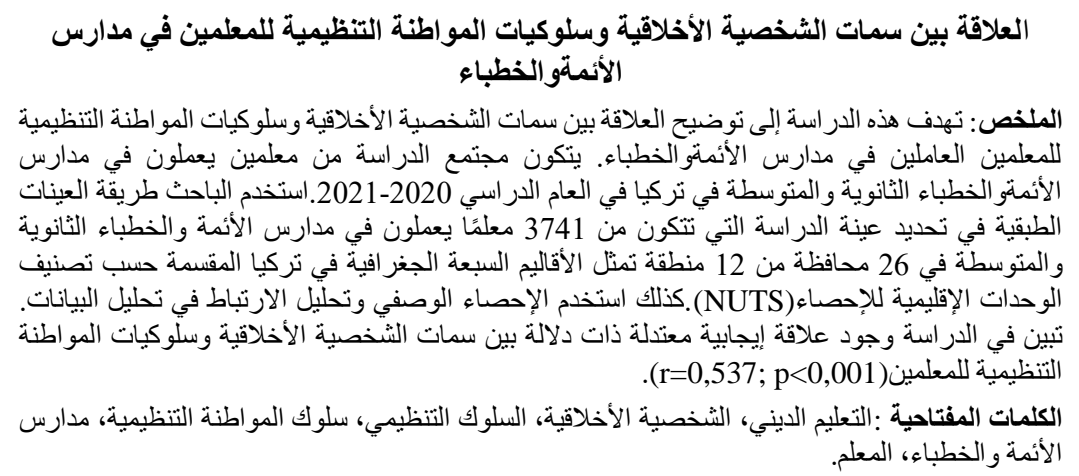

\section{Gíriş}

Ahlaki kişilik kavramı, ahlak psikolojisi alanında ele alınan bir kavram olmakla birlikte ona daha bilinçli ve özel bir ilgi duyulması nispeten yenidir. Bu gecikmenin nedenini "psikolojinin bu alanda yaşadığı kuramsal kararsızlık"1 ve "insanın ahlaki davranışlarını anlamada motivasyonel süreçlerin ve bireysel özelliklerin hesaba katılmaması" 2 şeklinde açıklayanlar vardır. Ahlaki kişilik genel anlamda "kişilerin ahlaki işlevlerini (ahlaki inanç/düşünce, ahlaki duygu ve özellikle ahlaki

1 Agusto Blasi, “Ahlaki Kişilik”, Değerler Ĕ̆itimi Ansiklopedisi, ed. Ronald J. Nuzzi vd. (İstanbul: Eğitim Danışmanlığı ve Araştırma Merkezi, 2018), 35.

2 Dan P. McAdams, "The Moral Personality", Personality, Identity, and Character: Explorations in Moral Psychology, ed. Darcia Narvaez, Daniel K. Lapsley (New York: Cambridge University Press, 2009), 11-29. 
eylemlerini/davranışlarını) etkileyen ve insan davranışlarının bu alandaki bireysel farklılıklarını belirleyen psikolojik özelliklerinin düzenlenişini ifade eden bir kavram"dır. ${ }^{3}$ Ahlak gelişimiyle ilgili literatür incelendiğinde ahlaki işlevlerin (moral functioning) temel unsurları arasında nasıl bir ilişki olduğuna dair önemli tartışmaların ve yaklaşımların olduğu görülmektedir. Ahlak, genellikle ahlaki biliş, ahlaki duygu ve ahlaki davranış boyutları olarak ele alınmaktadır. Ancak son yıllarda ahlakın dördüncü boyutu olarak ahlaki kişiliğe yönelik giderek artan bir ilgi söz konusudur. ${ }^{4}$

\section{Ahlaki Kişilik Yaklaşımları}

Her dönemde ahlak eğitimcilerinin ve teologların gelecek neslin nasıl daha iyi bir ahlaki hayat süreceklerine ve iyi bir ahlaki kişiliğe/karaktere sahip olacaklarına dair çeşitli çözüm önerileri vardır. Bu bağlamda kişilik kuramlarındaki temel varsayımları referans alan üç farklı ahlaki kişilik yaklaşımı söz konusudur.

Bu yaklaşımlardan birincisi özellik temelli yaklaşımdır. Bu yaklaşım, kişilikteki baskın eğilimler perspektifini benimseyerek davranışsal eğilimlerin özellikler tarafından iyi bir şekilde temsil edilebileceğini iddia eder. Başka bir ifadeyle, kişinin ahlakla ilgili çeşitli özelliklere sahip olması, ahlaki işleyişin öngörüsü olarak değerlendirilir. $\mathrm{Bu}$ anlamda kişilik psikologları tarafından kişiliği tanımlamak için geliştirilen Beş Faktörlü ve Altı Faktörlü kişilik yapıları temel alınarak kişilik boyutları ile ahlaki biliş, duyuş ve davranış arasında ilişki olduğu söylenebilir. ${ }^{5}$

İkinci yaklaşım sosyobilişsel yaklaşımdır. Bu yaklaşım, kişiliği bireyin iç dünyasındaki bilişsel-duygusal mekanizmalar bağlamında ele almakta ve bireysel farklılıkları, değişen durumsal bağlamlarla dinamik etkileşim içinde olan belirli, kişi içi psikolojik sistemler açısından açıklamaya çalışır. ${ }^{6}$ Sosyobilişsel yaklaşıma göre ahlaki kişilik, sosyal olayları yorumlamada ahlak şemalarının sürekli erişilebilirliğinde kişiye özgü farklılıklardır. Bu bakış açısıyla Lapsley ve Narvaez, ${ }^{7}$ ahlaklı bir kişinin ya da ahlaki bir kimliğe veya karaktere sahip bir kişinin, ahlaki kategorilere sürekli olarak erişilebildiğini iddia ederler. Kalıcı/sürekli olarak erişilebilir ahlaki şemalar, hem deneyimin ahlaki boyutlarını ayırt etmeye yönelik bir

3 Blasi, "Ahlaki Kişilik", 35.

4 John W. Santrock, A Topical Approach to Life-Span Development (New York: McGraw-Hill Education, 2019), 467.

5 Kibeom Lee - Michael C. Ashton, The H Factor Of Personality: Why Some People Are Manipulative, Self-Entitled, Materialistic, and Exploitive-and Why It Matters For Everyone. (Waterloo, ON, Canada: Wilfrid Laurier University Press, 2012); McAdams, "The Moral Personality".

6 Daniel Cervone, "Personality Architecture: Within-Person Structures and Processes", Annual Review of Psychology 56/1 (2005), 423-452.

7 Daniel K. Lapsley - Darcia Narvaez, "A Social-Cognitive Approach to the Moral Personality", Moral Development, Self, and Identity. (Mahwah, NJ, US: Lawrence Erlbaum Associates Publishers, 2004), 201. 
eğilim hazırlığı hem de duruma uygun davranışı seçmede bir ayırt etme yeteneği sağlar. Son yıllarda yapılan araştırmalar, ahlaki bilişin sosyal-bilişsel boyutlarını kanıtlamaya çalışmaktadır. Örneğin, söz konusu araştırmalar; iyi karakter, ${ }^{8}$ ahlaki, manevi ve dindar kişilik kavramlarının ${ }^{9}$ bilişsel prototipler olarak düzenlendiğini saptamıştır.

Son yaklaşım ise kişilikbilimsel yaklaşımdır. Kişilikbilimsel bir bakış açısıyla üç katmanlı bir kişilik tanımını referans alan McAdams, ${ }^{10}$ ahlaki kişilik kavramını kapsamlı bir şekilde açıklamaya çalışır. Birinci düzey; kapsamlı, koşulsuz, bağlamından koparılmış ve dolaylı olarak karşılaştırmalı boyutlar olarak ifade edilen eğilimsel özelliklerdir. İkinci düzey; zaman, yer ve/veya rol bağlamında kavramsallaştırılan kişiliğin motivasyonel ve stratejik yönleri olan karakteristik uyarlamaları içerir. Bu uyarlanabilir stratejiler, bireylerin ahlaki motivasyonunu genel özelliklerden daha iyi yakalayabilir. Üçüncü düzey ise yaşamda bir tutarlılık, anlam ve amaç duygusu sağlayan bir kimliğin psikososyal inşası olarak bütünleştirici yaşam anlatılarına atıfta bulunur. Yaşamlarının bu tür anlatımlarında insanlar, örtük ya da açık olarak benlik ve toplumla ilgili ahlaki bir duruş sergilerler ve bu nedenle, değişen ölçülerde kimliklerini ahlaki terimlerle inşa ederler.

Walker ve Frimer, örnek ahlaki kişilikleri (moral exemplars) konu alan çalışmasında ${ }^{11}$ çoklu ölçümlerle kişiliğin üç düzeyinin tümünü içerecek şekilde kapsamlı bir kişilik değerlendirmesi yaparak farklı kişilik profillerini ele almışlardır. $\mathrm{Bu}$ araştırmaya göre ilgi timsali katılımcıların (caring exemplars) cesaret timsali katılımcılara (brave exemplars) nazaran daha güçlü bakım/ilgi özelliklerine sahip olması, daha üretken kişisel çabalar göstermesi ve yaşam öyküleri boyunca daha fazla iyimserlik sergilemesi kişilik profillerindeki farklılıkları ortaya koymaktadır. Walker'a göre bu bulgular örüntüsü; ilgi timsali katılımcıların ahlaki eylemlerinin karakter ve motivasyon faktörlerine, cesaret timsali katılımcıların ahlaki eylemlerinin ise durumsal faktörlere atfedilebileceğini göstermektedir. ${ }^{12} \mathrm{Bu}$ bağlamda sadece durumsal ya da eğilimsel faktörleri temel alan tek boyutlu bir ahlaki kişilik anlayışı yerine çok boyutlu bir ahlaki kişilik anlayışının ahlaki duygu, düşünce ve davranışları anlama konusunda daha işlevsel olabileceği söylenebilir.

8 Daniel Lapsley - Benjamin Lasky, "Prototypic Moral Character", Identity 1/ (Ekim 2001), 345-363.

9 Lawrence J. Walker - Russell C. Pitts, "Naturalistic Conceptions of Moral Maturity", Developmental Psychology 34/3 (1998), 403-419.

10 McAdams, "The Moral Personality", 12-25.

11 Lawrence J. Walker - Jeremy A. Frimer, "Moral Personality of Brave and Caring Exemplars.", Journal of Personality and Social Psychology 93/5 (2007), 845-860.

12 Lawrence J. Walker, "Moral Personality, Motivation, and Identity", Handbook of Moral Development, ed. Melanie Killen, Judith G. Smetana (New York, NY, US: Psychology Press, 2014), 497-519. 
\begin{tabular}{l|l}
386 & İmam Hatip Okullarında Görev Yapan Öğretmenlerin Ahlaki Kişilik Özellikleri ve Örgütsel Vatandaşlık \\
RTEÜirD &
\end{tabular}

\section{Örgütsel Vatandaşlık Davranışı}

Örgütsel vatandaşlık davranışı (ÖVD) kavramı ilk olarak ABD'de yapılan çalışmalarda önerilmiş ve incelenmiştir. Örgütsel vatandaşlık davranışı kavramı kapsamlı ve sistemli olarak büyük ölçüde Bateman ve Organ tarafından ${ }^{13}$ ortaya konulmuş olup bu kavramın teorisi ve boyutları Organ tarafından geliştirilmiştir. ${ }^{14}$ Organ, örgütsel vatandaşlık davranışını "isteğe bağlı olan, resmi ödül sistemi tarafından doğrudan veya açıç̧a tanımlanmayan ve bir bütün olarak örgütün/kurumun etkin işleyişini destekleyen bireysel davranış" olarak tanımlamıştır. ${ }^{15}$ Başka bir ifade ile örgütsel vatandaşlık davranışı; bireylere veya bir bütün olarak kuruma yönelik, mevcut rol beklentilerinin ve faydalarının ötesine geçen ve kuruma fayda sağlamayı amaçlayan isteğe bağlı davranıştır. Örgütsel vatandaşlık davranışlarına ilişkin literatür incelendiğinde Organ tarafından ${ }^{16}$ özgecilik, vicdanlılık, centilmenlik, nezaket ve sivil erdem olarak kategorize edilen beş tür vatandaşlık davranışının örgütsel vatandaşlık davranışının anlaşılması ve değerlendirilmesi açısından önemli bir referans noktası olarak kabul edildiği görülmektedir. Bu araştırma kapsamında da benzer bir yaklaşım benimsenmiştir.

Özgecilik, örgütte veya kurumda işle ilgili sorunlarda veya görevlerde diğer kişilere gönüllü olarak yardım etmeyi amaçlayan davranışları ${ }^{17}$ vicdanlılık, örgüt üyelerinin bazı rol davranışlarını kendilerinden bekleneni aşan bir şekilde yerine getirmelerini ve iş görenin örgütün kurallarını, iş akışına ilişkin düzenlemeleri ve süreçleri içselleştirmesini; ${ }^{18}$ centilmenlik ise çalışanların örgütteki bireyler arasında çatışmaya neden olabilecek olumsuz davranışlardan kaçınmalarını, örgütte olması gereken durumlardan daha azına ve bu kapsamdaki kaçınılmaz rahatsızlıklara ve zorluklara gönüllü olarak hoşgörülü olmayı, işin dayatmalarına şikayet etmeden tahammül etme istekliliğini ifade etmektedir. ${ }^{19}$ Organizasyondaki iş bölümüne dayanan nezaket boyutu, örgütte iş yükümlülükleri nedeniyle sürekli iletişim halinde olmaları gereken ve birbirlerinin faaliyet ve kararlarından etkilenen iş görenlerin birbirlerini uyarma, birbirlerine danışma, bilgi paylaşımı ve hatırlatma gibi olumlu

13 Thomas S. Bateman - Dennis W. Organ, "Job Satisfaction and the Good Soldier: The Relationship Between Affect and Employee 'Citizenship.'”, Academy of Management Journal 26/4 (1983), 587-595.

14 Dennis W. Organ, Organizational Citizenship Behavior: The Good Soldier Syndrome. (Lexington, MA: Lexington Books, 1988).

15 Organ, Organizational Citizenship Behavior: The Good Soldier Syndrome., 4.

16 Organ, Organizational Citizenship Behavior: The Good Soldier Syndrome, 7-13.

17 Dennis W. Organ, “Organizational Citizenship Behavior: It's Construct Clean-Up Time”, Human Performance 10/2 (1997), 94.

18 Fatma Nur İplik, Örgütsel Vatandaşlık Davranışı (Ankara: Akademisyen Kitabevi, 2010), 59-61

19 Philip M. Podsakoff vd., “Organizational Citizenship Behaviors: A Critical Review of the Theoretical and Empirical Literature and Suggestions for Future Research", Journal of Management 26/3 (2000), 513-563. 
davranışlar göstermelerini içermektedir. Son boyut olarak sivil erdem ise iş görenin örgüt içindeki politik süreçlere ve örgütsel etkinliklere sorumluluk duygusuyla ve yapıcı bir şekilde katılımını ifade etmektedir. ${ }^{20}$

\section{Örgütsel Vatandaşlık Davranışına Etki Eden Faktörler}

Örgütsel vatandaşlık davranışına ilişkin literatürde yer alan araştırmaların büyük çoğunluğunda vatandaşlık davranışlarını ortaya çıkaran ve bireyleri bu tür davranışlara yönlendiren faktörler üzerinde durulmuştur. ${ }^{21} \mathrm{Bu}$ araştırma kapsamında ise örgütsel vatandaşlık davranışını etkileyen faktörler; bireysel özellikler, örgütsel özellikler, görev özellikleri ve liderlik davranışları olmak üzere 4 kategoride ele alınmıştır.

İş gören karakteristikleri olarak da isimlendirilen bireysel özellikler; iş görenin tutumları, kişilik özellikleri, iş görenin rol algıları, demografik değişkenler, iş görenin yetenekleri ve bireysel farklılıkları unsurlarından oluşur. Diğer bir faktör olan örgütsel karakteristikler ise örgütsel formalleşme, örgütsel esneklik, çalışma grubunun işbirliği ve koordinasyon içinde olması, danışmanlık/personel desteği gibi unsurları içerir. ${ }^{22}$ Çekici iş özellikleri ve itici iş özellikleri olmak üzere iki düzeyde incelenen $^{23}$ görev özellikleri ise eğitim ortamında öğretmenlerin öğretmenlik mesleğine ilişkin tutumlarını ve öğretmenlik mesleğine atfettikleri değeri ihtiva eder. Örgütsel vatandaşlık davranışlarının sergilenmesinde kilit rol oynayan son faktör olarak lider davranışları; liderin çalışanlara yardımcı olması, yol göstermesi ve örnek olacak davranışlar sergilemesi ${ }^{24}$ öğelerini içerir.

\section{Problem Durumu}

İnsanın bireyselleşmesi ve sosyalleşmesi sürecinde okul; etkisi ve sahip olduğu imkânlar açısından aileden sonra en önemli kurumdur. Cihan'a göre ${ }^{25}$ "Kültür aktarımında okul programında açık olarak belirtilen veya belirtilmeyen değerleri

20 Organ, Organizational Citizenship Behavior: The Good Soldier Syndrome, 12.

21 İplik, Örgütsel Vatandaşlık Davranışı; Soner Polat, Ortaöğretim Öğretmenlerinin Örgütsel Adalet Algıları, Örgütsel Güven Düzeyleri ile Örgütsel Vatandaşlık Davranışları Arasındaki İlişki (Kocaeli: Kocaeli Üniversitesi, Sosyal Bilimler Enstitüsü, Doktora Tezi, 2007); Philip M. Podsakoff vd., "Organizational Citizenship Behaviors: A Critical Review of the Theoretical and Empirical Literature and Suggestions for Future Research", Journal of Management 26/3 (2000), 513-563.

22 İplik, Örgütsel Vatandaşlık Davranışı,28-33.

23 Mustafayeva, Lale, Sosyal Sorumluluk ile Örgütsel Vatandaşlık Davranışları ve Örgütsel Özdeşleşme Arasındaki İlişkiye Yönelik Bir Araştırma (Kütahya: Dumlupınar Üniversitesi, Sosyal Bilimler Enstitüsü, Yüksek Lisans Tezi, 2007).

24 Murat Güven, Örgütsel Bağlılık ve Örgütsel Vatandaşlık Davranışı Arasındaki İlişki (İstanbul:Marmara Üniversitesi, Sosyal Bilimler Enstitüsü, Yüksek Lisans Tezi, 2006).

25 Nazlı Cihan, “Okullarda Değerler Eğitimi ve Türkiye'deki Uygulamaya Bir Bakış”, Journal of Turkish Studies 9/2 (2014), 429-436. 
öğretmek, öğrencileri belirlenen kurallar doğrultusunda hayata hazırlamak, ahlaki gelişime katkıda bulunmak, öğrencilerin karakterini ve benlik algısını olumlu yönde etkilemek okulların önemli görevleri arasında yer alır.” Bu bağlamda Din Öğretimi Genel Müdürlüğünün hazırlamış olduğu imam hatip okulları tanıtım kitapçığına göre $^{26}$ "millî ve manevi değerlerine bağlı, insanlığa faydalı olma idealine sahip, akademik eğitimini almış, karakterli ve güzel ahlaklı insanlar yetiştirmeyi" amaç edinen imam hatip okulları, ${ }^{27}$ Türk Milli Eğitim sistemi içindeki yeri açısından bu görevi yerine getirme konusunda önemli bir boşluğu doldurmaktadır. Bu amacı gerçekleştirme aşamasında en önemli görev öğretmenlere düşmektedir. Çünkü “öğretmenler sadece bilgi aktaran kişiler olarak değil, aynı zamanda davranışlarıyla ve yaşam tarzlarıyla da yol gösterici kimliğe sahiptirler." ${ }^{28}$ Aynı şekilde kişinin grupla ve grup normlarıyla özdeşleşme duygusu, ahlaki oluşumu başlatan veya bu oluşumu önemsiz kılan ahlaki atmosferin oluşmasında etkili olduğu için ${ }^{29}$ okul yönetimiyle birlikte birinci derecede ahlaki atmosferin oluşmasından sorumlu olan öğretmenlerdir. Bu bağlamda sınıf ortamında veya ders dışı etkinliklerde öğrencilere rol model olacak öğretmenlerin imam hatip okullarının karakterli ve güzel ahlaklı insanlar yetiştirme amacına ne ölçüde katkı sağlayacağı önemli bir problemdir. Kişilik gelişimi açısından ilköğretim ve ortaöğretim çağı öğrencilerinin akran gruplarından ve çevreden etkilenme durumları ve kimlik arayışları dikkate alındığında öğretmenlerin görev ve sorumlukları daha da önemli hale gelmektedir. ${ }^{30} \mathrm{Bu}$ görev ve sorumlukları yerine getirirken ve aynı zamanda okulun karakterli ve güzel ahlaklı insanlar yetiştirme amacına katkı sağlarken öğretmenlerin ahlaki kişilik özellikleri ve okullarında diğerlerini düşünme ve yardım etme, ileri görev bilinci, nezaket, örgütün gelişimine destek verme ve gönüllülük gibi davranışlar gösterme düzeylerinin tespit edilmesi ve açıklanması önemli bir araştırma konusu olarak belirmektedir. Yurtdışında ve ülkemizde kişilik ve örgütsel vatandaşlık davranışlarıyla ilgili son yıllarda çok sayıda çalışma ${ }^{31}$ olmasına rağmen ülkemizde ahlaki kişilik ile örgütsel

26 “Din Öğretimi Portalı" (Erişim 01 Ekim 2021).

27 Bu çalışmadaki İmam-Hatip Okulları ifadesi, Türk eğitim sistemi içerisinde yer alan İmam-Hatip Ortaokulları, Anadolu İmam Hatip Liseleri, Fen ve Sosyal Bilimler Programı Uygulanan Anadolu İmam Hatip Liseleri ve yabancı uyruklu öğrencilerin eğitim gördüğü Uluslararası Anadolu İmam Hatip Liselerinin tamamı için kullanılmaktadır.

28 Şenay Şen, “Eğitim Açısından Toplumsal Değişme ve Yenileşme”, Ĕ̆itim Bilimine Giriş, ed. Emin Karip (Ankara: Pegem Akademi, 2009), 176.

29 Daniel K.Lapsley, "Eğitimin Hedefi Olarak Ahlaki Öz Kimlik”, çev. Cengiz Şeker, Ahlak ve Karakter Ĕ̆itimi El Kitabı, ed. Larry P.Nucci Darcia Narvaez (İstanbul: Eğitim Danışmanlığı ve Araştırma Merkezi, 2019), 33-56.

30 Tarık Totan vd., “Öğretmen Adaylarının Mizaç Karakter ve Kimlik Özellikleri”, İnönü Üniversitesi Ĕ̆itim Fakültesi Dergisi 11/2 (2010), 19-43.

31 Selma Kaynak, Öğretmenlerin Kişilik Özellikleri ve Örgütsel Vatandaşlık Davranışı. (Afyon: Afyon Kocatepe Üniversitesi, Sosyal Bilimler Enstitüsü,Yüksek Lisans Tezi, 2007); Kübra Seynem 
vatandaşlık davranışları arasındaki ilişkiyi ele alan herhangi bir çalışma tespit edilmemiştir. Bu bağlamda araştırmanın temel problemini, "İmam hatip okullarında görev yapan öğretmenlerin ahlaki kişilik özellikleri ile örgütsel vatandaşlık davranışları arasında nasıl bir ilişki vardır?" sorusu oluşturmaktadır. Araştırmamızda ayrıca bu temel probleme bağlı olarak aşağıdaki sorulara da yanıtlar aranacaktır:

1. Öğretmenlerin ahlaki kişilik özelliklerine göre dağılımları nasıldır?

2. Öğretmenlerin okullarında gösterdikleri örgütsel vatandaşlık davranışı ve alt boyutlarına ilişkin algı düzeyleri nedir?

3. Katılımcıların ahlaki kişilik özellikleri ile örgütsel vatandaşlık davranışları arasında nasıl bir ilişki vardır?

Milli Eğitim Bakanlığının 2023 Eğitim Vizyonu'nunda ${ }^{32}$ da belirttiği gibi “Eğitim sisteminde; eğitim politikaları başta olmak üzere müfredat, materyal, teknoloji gibi alanlarda yapılan her türlü reform ve iyileştirme çabalarının başarısı, uygulamada büyük ölçüde öğretmenlerin ve okul yöneticilerinin mesleki yeterliliklerine, algılarına ve adanmışlıklarına bağlıdır." Bu bağlamda Türk Milli Eğitim Sistemi içerisinde önemli bir görev ifa eden imam hatip okullarında çalışan öğretmenlerin ahlaki kişilik özellikleri ile örgütsel vatandaşlık davranışları arasındaki ilişkinin ortaya konulmasının öğretmenlerin ve okul yöneticilerinin mesleki yeterliliklerine, algılarına ve adanmışlıklarına katkı sağlaması beklenmektedir. Ayrıca bu okulların geliştirilme ve iyileştirilme çabalarında saha araştırması olarak katkı sağlaması umulmaktadır.

\section{Yöntem}

İmam hatip okullarında görev yapan öğretmenlerin ahlaki kişilik özelliklerini ve gösterdikleri örgütsel vatandaşlık davranışlarına ilişkin algı düzeylerini betimlemeyi ve değişkenler arasındaki ilişkiyi açıklamayı amaçlayan bu araştırma, betimsel nitelikli ilişkisel tarama modeline dayalı yürütülen nicel bir çalışmadır. Araştırmada ahlaki kişilik özellikleri ile örgütsel vatandaşlık davranışları değişkenleri arasındaki birlikte değişimin (korelasyon) varlığı, yönü ve şiddeti belirlenmeye çalışıldığı için ilişkisel tarama modeli kullanılmıştır. ${ }^{33}$

Hacıahmetoğlu, Kişilik özelliklerinin örgütsel vatandaşlık davranışı üzerindeki etkisi: Özel bir eğitim kurumunda bir araştırma (İstanbul:Bahçeşehir Üniversitesi, Sosyal Bilimler Enstitüsü, Yüksek Lisans Tezi, 2020); Taya R. Cohen - Lily Morse, "Moral Character: What It Is and What It Does", Research in Organizational Behavior 34/ (2014), 43-61.

33 Ahmet. H. İslamoğlu - Ümit Alnıaçık, Sosyal Bilimlerde Araştırma Yöntemleri (İstanbul: Beta Basım Yayım Dağıtım, 2014), 97. 
\begin{tabular}{l|l}
390 & İmam Hatip Okullarında Görev Yapan Öğretmenlerin Ahlaki Kişilik Özellikleri ve Örgütsel Vatandaşlık
\end{tabular}

\section{Araştırmanın Evreni ve Örneklemi}

Araştırmanın çalışma evreni, 2020-2021 eğitim öğretim yılında Türkiye'deki yedi coğrafi bölgeyi temsilen İstatistiki Bölge Birimleri Sınıflandırmasına (IBBBS) göre bölgeler sınıflandırmasında Düzey 1'deki 12 bölgeden alınan 26 ildeki imam hatip liseleri ve ortaokullarında görev yapan öğretmenlerden oluşmaktadır. Tarama modelindeki araştırmanın örneklemi, oranlı tabakalama örneklem yoluyla seçilen 3710 öğretmenden oluşmaktadır.

Araştırmada tabaka olarak okul türleri [imam hatip ortaokulları (İHO), Anadolu imam hatip liseleri (AİHL), bünyesinde İHO bulunan AİHL (A $\dot{I} H L+\dot{I} H O)$ ve proje okulları] esas alınmıştır. Ana kitleden öngörülen miktarda tesadüfi olarak örnek çekilebilmesi için ana kitleyi kapsayan 26 ile (vilayete) ilişkin okul listesi, Din Öğretimi Genel Müdürlüğü Bilgi Sistemi Okul Listeleri kısmından alınarak oranlı bir şekilde örneklem çerçevesi oluşturulmuştur. Daha sonra ise bu tabakalardan basit tesadüfi örnekleme yöntemi ile okul listeleri oluşturularak bu okul listelerindeki bütün öğretmenler örnekleme dahil edilmiştir. Örneklem büyüklüğü belirlenirken \%95 güven düzeyinde $(\mathrm{z}=1,96)$ ve hata toleransı $\% 2$ olarak kabul edilmiştir. Örneklem hacmi https://www.surveysystem.com/sscalc.htm web sitesinden elektronik olarak minimum 2305 olarak hesaplanmıştır. COVID-19 bağlamında yüz yüze eğitime ara verilmesi nedeniyle veri toplama aracı, Din Öğretimi Genel Müdürlüğünün 20.11.2020 tarihli ve 98029973-605.01-E.17011439 sayılı yazısıyla http://dogm.meb.gov.tr/anket/ bağlantı adresinde yayınlanarak basit tesadüfi örnekleme yöntemi ile oluşturulan okul listesindeki katılımcıların erişimine açılmıştır. Ayrıca çalışma grubu dışındaki öğretmenlerin veri toplama aracına erişimini engellemek ve sadece örnekleme dahil okullarda görev yapan öğretmenlerin katılımını sağlamak için anket modülü şifrelenmiştir. Nihayetinde belirlenen süre zarfında toplam 3710 katılımcının araştırmaya katıldığı tespit edilmiştir. Yapılan değerlendirme sonucunda 68 ölçek formu değerlendirme dişı bırakılmış ve 3642 ölçek formu değerlendirmeye alınmıştır.

\section{Veri Toplama Araçları}

Belirlenen araştırma problemi kapsamında geniş bir literatür taraması yapılarak araştırmanın değişkenlerini en iyi şekilde ortaya koyacak ölçekler tespit edilmeye çalışılmıştır. Bu bağlamda veri toplamak amacıyla düzenlenen veri toplama aracı iki bölümden oluşmaktadır. Birinci bölümde öğretmenlerin demografik özelliklerini belirleyen maddelere, ikinci bölümde öğretmenlerin ahlaki kişilik özelliklerini ve örgütsel vatandaşlık davranışları algılarını ölçen maddelere yer verilmiştir. Katılımcıların erişimine sunulan ölçeklere ilişkin gerekli izinler ve etik kurul onayları alınmış olup ölçekler 5’li Likert tipi derecelendirmeye uygun olarak " $1=$ Kesinlikle 
katılmiyorum, 2=Katılmıyorum, 3=Kısmen katılıyorum, 4=Katıliyorum, 5=Kesinlikle katılıyorum" şekilde derecelendirilmiştir.

\section{Kısa Form Altı Faktörlü Kişilik Envanteri (HEXACO-PI-R)}

$\mathrm{Bu}$ araştırmada imam hatip okullarında görev yapan öğretmenlerin ahlaki kişilik özelliklerini ölçmek amacıyla HEXACO Kişilik Ölçeği (HKÖ-60) kullanılmıştır. Bu araştırmada ölçme aracı olarak kullanılan HEXACO Kişilik Ölçeği Kısa Formu (Hexaco Personality Inventory Revised 60), Dürüstlük/Alçak Gönüllülük (HonestyHumility), Dışadönüklük (Extraversion), Duygusallık (Emotionality), Uyumluluk (Agreeableness), Sorumluluk (Conscientiousness) ve Deneyime Açılık (Openness to Experience) olmak üzere kişiliğin altı temel boyutunu ölçmek amacıyla Lee ve Ashton tarafından geliştirilmiş ${ }^{34}$ ve Wasti, Lee, Ashton ve Somer tarafından Türkçeye uyarlanmıştır. ${ }^{35}$ Her biri 10 maddeden oluşan 6 faktör içeren orijinal ölçek, toplam 60 maddeden oluşmaktadır. Katılımcılar, ilgili maddeleri 5'li Likert tipi derecelendirme üzerinden yanıtlamakta olup orijinal ölçekteki her bir faktörden alınabilecek en düşük puan 10 ve en yüksek puan 50' dir. Her bir faktörden alınan yüksek puanlar, bireylerin kişilik özelliği düzeylerinin yüksekliğine işaret etmektedir. Ölçekte 29 madde $(1,9,10$, $12,14,15,19,20,21,24,26,28,30,31,32,35,41,42,44,46,48,49,52,53,55,56,57,59$ ve 60) ters puanlanmaktadir.

Ölçeğin yapı geçerliği AFA ile incelenmiştir. AFA yapılmadan önce veri setinin faktör analizi için uygunluğuna Kaiser-Meyer-Olkin (KMO) ve Barlett Sphericity testleriyle bakılmıştır. Büyüköztürk'e göre elde edilen veri seti ile faktör analizinin yapılması için Bartlett testinin anlamlı ve KMO sonucunun .60'dan büyük olması gerekmektedir. ${ }^{36}$ Yapılan analiz sonucu KMO değeri .78 ve Barlett Sphericity testi değeri 14727,55 ( $\mathrm{df}=276 \mathrm{p}=.000)$ olarak tespit edilmiştir. HEXACO Kişilik Envanteri'nin KMO ve Barlett testi değerleri incelendiğinde, veri setinin faktör analizi için uygun olduğu anlaşılmaktadır. HEXACO Kişilik Envanteri'ni geliştiren Lee ve Ashton'ın önerdiği gibi 24 alt boyuta temel bileşenler faktör analizi (principal axis factor analysis) uygulanarak daha az değişkenle faktör varyanslarının maksimum olması sağlanacak şekilde Varimax dik döndürme yapılmıştır. ${ }^{37}$ Faktör yük değerleri ve açıklanan toplam ortak varyans Tablo 1'de gösterilmiştir.

34 Inventory", Multivariate Behavioral Research 39/2 (2004), 329-358.

35 S. Arzu Wasti vd., "Six Turkish Personality Factors and the HEXACO Model of Personality Structure", Journal of Cross-Cultural Psychology 39/6 (2008), 665-684.

36 Şener Büyüköztürk, Sosyal Bilimler İçin Veri Analizi El Kitabı (Ankara: Pegem Akademi Yayıncılık, 2012), 126

37 Lee - Ashton, "Psychometric Properties of the HEXACO Personality Inventory". 
Tablo 1. HEXACO Kişilik Envanteri Faktör Yük Değerleri ve Ortak Varyans

\begin{tabular}{|c|c|c|c|c|c|c|}
\hline HEXACO & Faktör & & & & & \\
\hline Alt boyutlar & 1 & 2 & 3 & 4 & 5 & 6 \\
\hline Düzenlilik (Organization) & .685 & & & & & \\
\hline $\begin{array}{l}\text { Mükemmeliyetçilik } \\
\text { (Perfectionism) }\end{array}$ & .684 & & & & & \\
\hline Tedbirlilik (Prudence) & .657 & & & & & \\
\hline Çalışkanlık (Diligence) & .560 & & & & & \\
\hline Sosyallik (Sociability) & & .706 & & & & \\
\hline $\begin{array}{l}\text { Sosyal Girişkenlik } \\
\text { (Socialboldness) }\end{array}$ & & .681 & & & & \\
\hline Zindelik (Liveness) & & .675 & & & & \\
\hline $\begin{array}{l}\text { Sosyal Özsayg1 } \\
\text { (Socialselfesteem) }\end{array}$ & & .572 & & & & \\
\hline Bağımlılık (Dependence) & & & .715 & & & \\
\hline $\begin{array}{l}\text { Duygusallık } \\
\text { (Sentimentality) }\end{array}$ & & & .660 & & & \\
\hline Korku (Fearfulness) & & & .656 & & & \\
\hline Kayg1 (Anxiety) & & & .611 & & & \\
\hline $\begin{array}{l}\text { Estetik değerleme } \\
\text { (Aestheticappreciation) }\end{array}$ & & & & .719 & & \\
\hline $\begin{array}{l}\text { Geleneksel Olmama } \\
\text { (Unconventionality) }\end{array}$ & & & & .690 & & \\
\hline Creativity (yaratıcılık) & & & & .653 & & \\
\hline $\begin{array}{l}\text { Meraklılık } \\
\text { (Inquisitiveness) }\end{array}$ & & & & .598 & & \\
\hline Nezaket (Gentleness) & & & & & .760 & \\
\hline Sabır (Patience) & & & & & .738 & \\
\hline Esneklik (Flexibility) & & & & & .642 & \\
\hline $\begin{array}{l}\text { Bağışlayıcılık } \\
\text { (Forgiveness) }\end{array}$ & & & & & .497 & \\
\hline $\begin{array}{l}\text { Alçakgönüllülük } \\
\text { (Modesty) }\end{array}$ & & & & & & .682 \\
\hline $\begin{array}{l}\text { Kanaatkârlık } \\
\text { (Greedavoidance) }\end{array}$ & & & & & & .657 \\
\hline Adalet (Fairness) & & & & & & .525 \\
\hline Samimiyet (Sincerity) & & & & & & .495 \\
\hline $\begin{array}{l}\text { Varyansı Açıklama } \\
\text { Yüzdesi }\end{array}$ & 14,75 & 9,34 & 8,75 & 6,85 & 5,93 & 5,04 \\
\hline Toplam Yüzde & 14,75 & 24,09 & 32,83 & 39,68 & 45,62 & 50,67 \\
\hline
\end{tabular}

Tablo 1'e göre HEXACO Kişilik Envanteri'nin alt boyut faktör yüklerinin .495 ile .760 arasında değiştiği görülmektedir. Genel olarak faktör yüklerinin .40 ve üzerinde olması durumunda anlamlı bir yükleme olduğu söylenebilir. ${ }^{38} \mathrm{Bu}$ bağlamda,

38 Ümit Alnıaçık, Sosyal Bilimlerde Araştırma Yöntemleri, 407 
HEXACO Kişilik Envanteri'nin faktör yük değerlerinin yeterli düzeyde olduğu anlaşılmaktadır. Bu araştırma kapsamında yapılan iç tutarlılık güvenirlik analizi sonuçlarına göre tüm ölçeğin Cronbach Alfa değeri .76 olarak bulunmuştur. Faktör analizine dayalı boyutlar için yapılan güvenirlik hesaplamasında dürüstlük-alçak gönüllülük faktörünün .62, duygusallık faktörünün .73, dişadönüklük faktörünün .74, uyumluluk faktörünün .65, sorumluluk faktörünün .72, deneyime açıklık faktörünün .68 iç tutarlılık güvenirlik katsayısı gösterdiği hesaplanmıştır. Ölçeğin alt boyutları ve tümü için hesaplanan Cronbach Alfa değerleri $0.60 \leq \alpha \leq 0.80$ arasında yer aldığı için Alfa katsayısına bağlı olarak Altı Faktörlü Kişilik Envanteri'nin oldukça güvenilir olduğu söylenebilir. ${ }^{39}$

Bu çalışmada Altı Faktörlü Kişilik Envanteri'nin (HEXACO-KE-Tr) seçilmesinin nedeni; Beş Faktör Kişilik Envanteri'nden farklı olarak dürüstlük/alçak gönüllülük boyutunun ahlaki kişilik hakkında önemli bilgiler içermesidir. Ayrıca Chuang ve Chiu $^{40}$, Cohen ve Morse ${ }^{41}$, McFerran, Aquino ve Duffy ${ }^{42}$ gibi birçok araştırmacı da çalışmalarında Büyük Beşli ve Altı Faktörlü Kişilik Modellerinin boyutlarından yararlanarak ahlaki kişiliği, ahlakla ilgili kişilik özellikleri olarak tanımlamışlardır. Bu bağlamda araştırmamızda ahlaki kişilik, HEXACO Kişilik Envanteri'nin dürüstlükalçak gönüllülük, uyumluluk, sorumluluk ve deneyime açıklık boyutlarının toplamı olarak işlevselleştirilmiştir.

\section{Örgütsel Vatandaşlık Davranışı Algısı Ölçeği}

Araştırmada örnekleme alınan okullarda görev yapan öğretmenlerin örgütteki vatandaşlık davranışlarını ölçmek amacıyla Podsakoff vd. ve Moorman tarafından geliştirilen $^{43}$ ve Polat tarafından Türkçeye uyarlanan ${ }^{44}$ "Örgütsel Vatandaşlık Davranışı Algısı Ölçeği” kullanılmıştır. Polat tarafından lise öğretmenleri örneklemi üzerinde yapılan uyarlama çalışmasında, aslı 5 boyutlu olan ölçek, 4 boyut olarak sınıflandırılmıştır. Ölçeğin aslındaki yardımlaşma ve nezaket boyutunda yer alan

Pd., "Organizational Citizenship Behaviors: A Critical Review of the Theoretical and Empirical Literature and Suggestions for Future Research", 2000; Robert H. Moorman, "Relationship Between Organizational Justice And Organizational Citizenship Behaviors: Do Fairness Perceptions Influence Employee Citizenship?", Journal of Applied Psychology 76/6 (1991), 845-855.

44 Polat, Ortaögrretim Öğretmenlerinin Örgütsel Adalet Algıları, Örgütsel Güven Düzeyleri ile Örgütsel Vatandaşlık Davranışları Arasındaki İlişki. 
maddeler bir boyutta toplanmıştır. ${ }^{45}$ Diğer maddeler asıl ölçekle tutarlı olarak sınıflanmıştır. Bu çalışma kapsamında ölçeğin yapı geçerliği açımlayıcı faktör analizi ile incelenmiştir. Yapılan analiz sonucu KMO değeri .93 ve Barlett Sphericity testi değeri 32047,589 (df= 190 p= .000) olarak belirlenmiştir. Literatüre uygun olarak ölçekteki toplam 20 maddeye bileşenler faktör analizi uygulanarak Varimax dik döndürme yapılmıştır. Faktör yük değerleri ve açıklanan toplam ortak varyans Tablo 2'de gösterilmiştir.

\section{Tablo 2.Örgütsel Vatandaşlık Davranışı Algısı Ölçeği Faktör Yük Değerleri ve Ortak Varyans}

\section{Ölçek Maddeleri}

Boyutlar

3- Öğretmen arkadaşlarımın sorunu olduğunda onlara yardım etmek için gönüllü olarak zaman ayırırım.

5- Okulumla ilgili bir karar almadan önce bu kararın sonucundan etkilenecek arkadaşlarımın fikirlerini alırım.

1-İş yükü ağır olan öğretmen arkadaşlarıma yardım ederim.

.747

2-Zamanım uygunsa, dersine herhangi bir sebeple gelemeyen ya da geciken arkadaşımın yerine derse girerim.

6-Öğretmen arkadaşlarımın haklarını korumaya özen gösteririm.

4- Okula yeni atanan öğretmenler yardım istemeseler bile onlara yardimci olurum.

8-İşimle ilgili önemli bir adım atmadan önce yöneticilerimi mutlaka bilgilendiririm.

Y C $\quad$ V $\quad$ SE

\section{.780}

7-Öğretmen arkadaşlarımla aramda çıkabilecek olası sorunlar için önceden önlemler alırım.

.723

.712

.708

.627

\section{.575}

9-Okulda zamanımın çoğunu okuldaki iş ve uygulamalardan şikayet ederek geçiririm.

.771

12-Okulun olumlu yönlerinden çok olumsuz yönlerine odaklanırım.

10-Okulumdaki küçük sorunları büyütebilirim. $\quad .750$

11-Etrafımdakilere sürekli öğretmenliği bırakmak istediğimi söylerim. $\quad .730$

\begin{tabular}{ll}
\hline 14-Teneffüs aralarını asla uzatmam. & .823
\end{tabular}

15-Teneffüs zamanı dışında isime ara vermem.

$\begin{array}{ll}\text { 13- İşime zamanında gelirim. } & .744\end{array}$

16-Kimse denetlemese bile okul kurallarına, yönetmeliklerine ve işlem basamaklarına uyarım.

19-Okulu ilgilendiren tüm toplantılara katılarak tartışmalara aktif olarak katılırım.

17-Okuldaki değişiklikleri izler, öğretmen arkadaşlarımın bu değişiklikleri kabul etmeleri için aktif rol alırım. 
18-Okulumuzun imajını güçlendiren tüm etkinliklere gönüllü olarak katılırım.

20-Okuldaki değişikliklere ayak uydurmaya çalışırım.

\begin{tabular}{|c|c|}
\hline Varyansı Açıklama Yüzdesi & $38,36 \quad 8,79 \quad 7,21 \quad 6,90$ \\
\hline Toplam Yüzde & $38,3647,1654,3861,29$ \\
\hline
\end{tabular}

Örgütsel Vatandaşlık Davranışı Algısı Ölçeği alt boyut faktör yüklerinin .484 ile .823 arasında değiştiği görülmektedir. Faktör yük değeri olarak alınan .40 kesme noktası değerine göre tüm maddelerin kabul edilebilir değerler arasında olduğu görülmüştür. Buna göre, dört faktöre göre açıklanan değişkenlere baktığımızda ölçekteki 20 madde verilerdeki toplam varyansın yaklaşı \%61,29'unu açıklamaktadır. Bu çalışmanın örnekleminden elde edilen veriler doğrultusunda yapılan güvenirlik analizinde tüm ölçeğin Cronbach Alfa değeri .91 olarak bulunmuştur. Faktör analizine dayalı boyutlar için yapılan güvenirlik hesaplamasında ise yardımlaşma boyutunda .87; centilmenlik boyutunda .81; vicdanll1ık boyutunda .83 ve sivil erdem boyutunda ise .80 değerleri bulunmuştur.

\section{Verilerin Analizi}

Verilerin analizine başlamadan önce yapılması gereken ilk şey veri setinin hatalara karşı kontrol edilmesidir. Bu kapsamda öncelikle hatalı ve kayıp veri olup olmadığı incelenmiştir. İnceleme sonucunda hatalı veri girişi (hep aynı verinin girilmesi) yapılan 38 veri seti analiz dışı bırakılmıştır. Veri toplama araçları, http://dogm.meb.gov.tr/anket/ bağlantı adresinde yayınlanmış ve bir maddeyi doldurmadan diğer maddeye geçişe izin verilmediği için kayıp verimizin olmadığı tespit edilmiştir. Araştırmanın diğer bir adımı da uç değerlerin incelenmesidir. Tek değişkenli uç değerlerin incelenmesinde $\mathrm{Z}$ puanları hesaplanmıştır. $\mathrm{Z}$ puanı +3 'ten büyük ve $-3^{\prime}$ ten küçük denekler, uçdeğer olarak görülmüş ve incelenmiştir. ${ }^{46}$ Hatalı girilmediği tespit edilen ancak gelişi güzel doldurulduğu için uç değer olarak görülen 30 veri seti daha analizden çıarılmıştır. Sonraki aşamada ise araştırma verilerinin tek değişkenli normallik varsayımlarını karşılayıp karşılamadığı incelenmiştir. Bu araştırmada Kolmogorov-Simirnov testi "büyük örneklemlerde normallik hipotezini reddetmesi olasıllı̆̆ yüksek olduğu" için tercih edilmemiştir. ${ }^{47}$ Bunun yerine araştırma değişkenlerine ilişkin çarpıklık ve basıklık katsayıları normallik dağılımı için esas alınmış ve ahlaki kişilik değişkeninin çarpıklık değeri -.018; basıklık değeri .003; örgütsel vatandaşlık davranışı değişkeninin çarpıklık değeri -.550, basıklık

46 Yalçın Karagöz, SPSS ve AMOS Uygulamalı Nitel-Nicel-Karma Bilimsel Araştırma Yöntemleri ve Yayın Etĭgi (Ankara: Nobel Akademik Yayıncilık, 2017), 111.

47 David C. Howell, Statistical Methods for Psychology (Belmont, CA: Wadsworth, Cengage Learning, 2012), 78 . 
değeri .584 olarak tespit edilmiştir. Çarpıklık ve basıklık katsayısının +1 ile -1 arasında değer alması normalliğin bir göstergesi olarak değerlendirilmektedir. ${ }^{48} \mathrm{Bu}$ durumda araştırmamızın değişkenine ilişkin çarpıklık ve basıklık katsayısının normallik için sınır değerler içerisinde yer aldığı söylenebilir. Veri analizinin son aşamasını araştırma değişkenleri ile ilgili betimsel istatistikler; aritmetik ortalama, standart sapma ve korelasyon değerleri vb. oluşturmaktadır. Aritmetik ortalamaların yorumlanabilmesi için aralıklar 1.00-1.79 "çok düşük", 1.80-2.59 "düşük", 2.60-3.39 "orta", 3.40-4.19 "yüksek", 4.20-5.00 aralığ1 ise "çok yüksek" olarak değerlendirilmiştir. ${ }^{49}$

\section{Öğretmenlerin Ahlaki Kişilik Özellikleri Dağılımına İlişkin Bulgular ve Yorumlar}

Öğretmen görüşlerine göre ahlaki kişilik özelliklerinin dürüstlük/alçak gönüllülük, uyumluluk, sorumluluk ve deneyime açıklık alt boyutlarına ilişkin bulgulara Tablo 3 'te yer verilmiştir.

Tablo 3. Öğretmenlerin Ahlaki Kişilik Özelliklerine İlişkin Dağılımları

\begin{tabular}{lccc}
\hline \multicolumn{1}{c}{ Boyut } & $\mathbf{N}$ & $\overline{\mathbf{X}}$ & SS \\
\hline Dürüstlük/Alçakgönüllülük & 3642 & 4,11 & 0,44 \\
Uyumluluk & 3642 & 3,43 & 0,50 \\
Sorumluluk & 3642 & 3,78 & 0,52 \\
Deneyime açıklık & 3642 & 3,60 & 0,54 \\
Ahlaki Kişilik & 3642 & 3,73 & 0,30 \\
\hline
\end{tabular}

Tablo 3'te öğretmenlerin ahlaki kişilik özelliklerini iş yaşamında sergilemelerine ilişkin tanımlayıcı istatistikler incelendiğinde, öğretmenlerin ahlaki kişilik puan ortalaması ( $\bar{X}=3,73$ ) olarak bulunmuş ve ahlaki kişilik özellikleri alt boyutlarından ise en fazla dürüstlük/alçak gönüllülük $(\bar{X}=4.11)$ ve en az uyumluluk $(\bar{X}=3,43)$ boyutlarında puan aldıkları görülmüştür Bütün boyutlar dikkate alındığında öğretmenlerin ahlaki kişilik ve alt boyutlarından elde ettikleri toplam puan ortalamalarının "yüksek düzeyde" olduğu söylenebilir.

HEXACO Kişilik Envanteri'nin ölçme aracı olarak kullanıldı̆̆ı kişilikle ilgili çalışmalar incelendiğinde ve ahlaki kişiliğin dört boyutu esas alındığında katılımcıların en düşük ortalamayı uyumluluk boyutunda aldıkları tespit edilmiştir. ${ }^{50}$

48 Şener Büyüköztürk, Sosyal Bilimler İçin Veri Analizi El Kitabı, 40.

49 Polat, Ortä̈̆gretim Öğretmenlerinin Örgütsel Adalet Alglları, Örgütsel Güven Düzeyleri ile Örgütsel Vatandaşlık Davranışları Arasındaki İlişki.

50 Michael C. Ashton vd., "The HEXACO Honesty-Humility, Agreeableness, and Emotionality Factors: A Review of Research and Theory", Personality and Social Psychology Review 18/2 (2014), 139-152; Ezgi Cömert, Cinsiyete Göre Üniversite Öğrencilerinde Karanlık Üçlü: Hexaco Kişilik Özelliklerinin Yordayıcı Rolü (Mersin: Çağ Üniversitesi, Sosyal Bilimler Enstitüsü, Yüksek Lisans Tezi, 2018); Isabel Thielmann vd., “On Measuring the Sixth Basic Personality Dimension: A 
$\mathrm{Bu}$ sonuçlar araştırmamızın bulgusu ile uyumludur. Yine aynı şekilde Thielmann vd. ${ }^{51}$ ile Ulu ve Bulut ${ }^{52}$ en yüksek ortalamanın dürüstlük-alçak gönüllülï̈k boyutunda olduğunu belirtmişlerdir. Bu sonuçlar da araştırma bulgumuz ile tutarlıdır. Araştırma verilerine göre imam hatip okullarında görev yapan öğretmenlerin yüksek düzeyde ahlaki kişilik özelliklerine sahip oldukları görülmüştür. Ayrıca öğretmenlerin ahlaki kişiliğin alt boyutlarında da yüksek düzeyde puan almaları onların bireyler arası ilişkilerde ve kurumsal görevlerde kişilik boyutlarının avantajlarından yararlanmalarına katkı sağlayabileceği söylenebilir.

Dürüstlük-alçak gönüllülük bir kişinin, kişisel alçak gönüllülüğün yanı sıra etik ve ahlaki davranış standartlarına ne ölçüde değer verdiğini ve bunlara ne ölçüde bağlı olduğunu açıklar. ${ }^{53} \mathrm{Bu}$ bağlamda ahlaki kişiliğin dürüstlük-alçak gönüllülük boyutundan yüksek puan almaları öğretmenlerin adil olma, yasalara saygılı olma, başkalarını manipüle etmekten ve ikiyüzlü olmaktan kaçınma, gösterişten uzak durma, kendilerini üstün görmeme eğiliminde oldukları şeklinde yorumlanabilir.

Sorumluluk boyutunda yüksek düzeyde bulunan bireyler; disiplinli, gayretli, düzenli, programlı, azimli, çalışkan, dikkatli, kontrollü, tedbirli, iradeli, prensip sahibi gibi özelliklerle tanımlanırlar. Düşük düzeyde bulunanlar ise gayretsiz, tembel, gevşek, sorumsuz, beceriksiz, dağınık, dalgın, dikkatsiz, dengesiz gibi özellikler taşırlar. ${ }^{54}$ Yapılan birçok araştırma ${ }^{55}$ sonucunda sorumluluk özelliğinin iş başarısıyla ilişkili olduğu ve neredeyse tüm işler için aranan bir özellik olduğu bulunmuştur. Tüm kişilik boyutları içinde performansla en fazla ilişkili bulunan boyut sorumluluk boyutu olmuştur. ${ }^{56}$ Dolayısıyla sorumluluk düzeyi yüksek öğretmenler, sorumluluk düzeyi düşük öğretmenlere göre okuldaki ve okul dişı etkinliklerde daha iyi performans gösterme eğiliminde olacaklardır. $\mathrm{Bu}$ bakımdan örneklemdeki

Comparison Between HEXACO Honesty-Humility and Big Six Honesty-Propriety", Assessment 24/8 (2017), 1024-1036.

51 Thielmann vd., "On Measuring the Sixth Basic Personality Dimension: A Comparison Between HEXACO Honesty-Humility and Big Six Honesty-Propriety".

52 Mustafa Ulu - Meryem Berrin Bulut, “Üniversite Öğrencilerinin Kişilik Özelliklerinin Hexaco İle Ölçülmesi", Bilimname 34/ (2017), 443-463.

53 Samuel T. Mcabee Vd., "The HEXACO Model in Education and Work: Current Applications and Future Directions", Zeitschrift für Psychologie 227/3 (2019), 174-185.

54 Oya Somer, “Türkçe'de Kişilik Özelliği Tanımlayan Sıfatların Yapısı ve Beş Faktör Modeli”, Türk Psikoloji Dergisi 13/42 (1998), 17-32.

55 H. Sjahruddin vd., "Personality Effect on Organizational Citizenship Behaviour (OCB): Trust in Manager and Organizational Commitment Mediator of Organizational Justice in Makassar City Hospitals (Indonesia", European Journal of Business and Management 5/9 (2013), 95-104.

56 Deniz S. Ones vd., "Comprehensive Meta-Analysis of Integrity Test validities: Findings and Implications for Personnel Selection and Theories of Job Performance", Journal of Applied Psychology 78/4 (1993), 679-703. 
öğretmenlerin okul içi ve okul dışı eğitim etkinliklerinde iyi performans gösterme eğilimine sahip oldukları söylenebilir.

Hızla değişmekte olan günümüz dünyasında öğrenen örgütlerin ve bireylerin yeni ihtiyaçlara göre hareket edilerek geliştirilmesi ve örgütlerin performanslarını arttırabilmek için bilgiyi kullanmaya ve sürekli öğrenmeye odaklanmaları gerektiği anlayışına $^{57}$ göre yüksek düzeyde deneyime açıklık özelliklerine sahip bireylerden oluşan bir kurum diğer kurumlara nazaran hizmet alanlarında önemli avantajlara sahip olacaktır. Bu açıdan imam hatip okullarının istenen özelliklerde insan kaynağ potansiyeline sahip olduğu söylenebilir.

Uyumluluk düzeyi yüksek insanlar, kendisiyle anlaşılması zor olan insanlarla geçinmeye yatkındırlar. Hoşgörülü ve sabırlı olma eğilimine sahiptirler. ${ }^{58} \mathrm{Bu}$ bağlamda yüksek uyumluluk düzeyindeki öğretmenler, ikili ilişkileri sürdürme konusunda daha başarılıdırlar. Çünkü uyumluluk boyutu, başkaları tarafından kullanıldığı hissiyatı oluşsa bile başkalarıyla iş birliği yapma anlamında hoşgörü ve affetmenin kişilik özellikleri düzeyinde tezahürünü somutlaştıran farklı bir tamamlayıcı özgecil endişeyi yansıtır. ${ }^{59}$

\section{Öğretmenlerin Örgütsel Vatandaşlık Davranışı Algı Düzeylerine İlişkin} Bulgular ve Yorumlar

Öğretmen görüşlerine göre öğretmenlerin örgütsel vatandaşlık davranışı alg1 düzeylerine ilişkin bulgulara Tablo 4 'te yer verilmiştir.

Tablo 4. Öğretmenlerin Örgütsel Vatandaşlık Davranışı Algı Düzeyleri

\begin{tabular}{lccc}
\hline \multicolumn{1}{c}{ Boyut } & $\mathbf{N}$ & $\overline{\mathbf{X}}$ & SS \\
\hline Yardımlaşma & 3642 & 4,21 & 0,49 \\
Centilmenlik & 3642 & 4,34 & 0,63 \\
Vicdanlılık & 3642 & 4,43 & 0,58 \\
Sivil Erdem & 3642 & 3,92 & 0,63 \\
Örgütsel Vatandaşlık Davranışı & 3642 & 4,22 & 0,44 \\
\hline
\end{tabular}

Tablo 4'te görüldüğü gibi öğretmenlerin örgütsel vatandaşlık davranışına ilişkin puan ortalaması $(\bar{X}=4,22)$, olarak elde edilmiştir. Alt boyutlara ilişkin ortalama puanlar incelendiğinde öğretmenlerin puanları örgütle ilgili bir görevde veya

57 Soner Doğan - Yakup Yiğit, “Öğreten Okulların Tamamlayıcısı: Öğrenen Okullar”, Elektronik Sosyal Bilimler Dergisi 14/53 (2015), 318-336.

58 Lee - Ashton, The H Factor of Personality: Why Some People are Manipulative, Self-Entitled, Materialistic, and Exploitive-and Why It Matters for Everyone.

59 Antonio Chirumbolo - Antonio Leone, "Personality and Politics: The role of The HEXACO Model of Personality in Predicting Ideology and Voting.", Personality and Individual Differences 49/1 (2010), 43-48. 
problemde örgütün diğer çalışanlarına yardım etmeye yönelik gösterdikleri gönüllü davranışları ifade eden yardımlaşma boyutunda $(\bar{X}=4,21)$, çalışanların örgüt içinde gerginliğe sebep olacak olumsuz davranışlardan kaçınmalarını ve olumsuzluklara rağmen örgüte ilişkin olumlu düşünmelerini ifade eden centilmenlik boyutunda ( $\bar{X}=$ 4,34), örgüt üyelerinin kendilerinden beklenen minimum rol davranışının ötesinde bir davranış sergilemeye gönüllü olmasını ifade eden vicdanlılık boyutunda $(\bar{X}=4,43)$, çalışanların yönetime gönüllü olarak katılımını ifade eden sivil edem boyutunda ise ( $\overline{\mathrm{X}}=3,92$ ) olarak tespit edilmiştir. Örgütsel vatandaşlık davranışına ilişkin olarak elde edilen toplam puan ortalaması $(\bar{X}=4,22)$, çok yüksek düzeyde bir örgütsel vatandaşlık davranışı anlamına gelmektedir. Benzer şekilde öğretmenlerin ÖVD algısının yardımlaşma, centilmenlik ve vicdanlılık boyutlarında "çok yüksek düzeyde"; sivil erdem boyutunda ise "yüksek düzeyde" olduğu anlaşılmaktadır Ayrıca boyutlar arasındaki ortalama puanlar incelendiğinde öğretmenlerin ÖDV alg1 düzeylerinin en fazla vicdanlılık ( $\bar{X}=4,43)$, en az sivil erdem $(\bar{X}=3,92)$ boyutlarında olduğu görülmektedir. Bu bulgular, Polat'ın ${ }^{60}$ ve Dağl1'nın ${ }^{61}$ çalışmalarındaki bulgularla paralellik arz etmektedir. Her iki araştırmada da sırasıyla öğretmenlerin en fazla vicdanlılık $(\bar{X}=4,27), \quad(\bar{X}=4,26)$, en az sivil erdem $(\bar{X}=3,92), \quad(\bar{X}=3,96)$ boyutlarında puan aldıkları tespit edilmiştir. $\mathrm{Bu}$ verilerden hareketle imam hatip okullarında görev yapan öğretmenlerin okullarının hedeflerine ulaşması için fedakârlık gösterme, karşılaştıkları birçok sıkıntıya katlanma ve resmi rol gereklerinin dışındaki eylemleri kapsayan ekstra rol davranışlarını gösterme eğiliminde oldukları söylenebilir. Elde edilen bu bulgulara göre, imam hatip okullarında çalışan öğretmenlerin örgütsel vatandaşlık davranışı algı düzeyi puanlarının alt boyutlarda ve toplam ÖVD'de ortalamaların üstünde olması katılımcı öğretmenlerin okullarında ÖVD’yi sergilemeye dair olumlu görüşe sahip oldukları şeklinde yorumlanabilir.

\section{Ahlaki Kişilik Özellikleri ile Örgütsel Vatandaşlık Davranışları ve Alt Boyutları Arasındaki İlişki}

Öğretmenlerin ahlaki kişilik özellikleri ile örgütsel vatandaşlık davranışları arasındaki ilişkiyi belirlemeye yönelik yapılacak analizler için öncelikle öğretmenlerin ahlaki kişilik özellikleri ve örgütsel vatandaşlık davranışları algılama düzeyi puanlarının dağılımlarının çarpıklık ve basıklık değerleri esas alınarak normal dağılım gösterdiği belirlenmiştir. Buna göre araştırma verileri parametrik test özelliği sağladığı için Pearson momentler korelasyonu ile analiz yapılmıştır.

60 Polat, Ortaöğretim Öğretmenlerinin Örgütsel Adalet Algılarn, Örgütsel Güven Düzeyleri ile Örgütsel Vatandaşlık Davranışları Arasındaki İlişki.

61 Emine Dağll, Ilköğretim Okullarında Müdürlerin Kullandıkları Etkileme Taktiklerinin Öğretmenlerin Örgütsel Vatandaşlık Davranışları ve Okul Farkındalı̆̆ ile Iliş̧kisi (Gaziantep:Gaziantep Üniversitesi, Eğitim Bilimleri Enstitü, Doktora Tezi, 2015). 


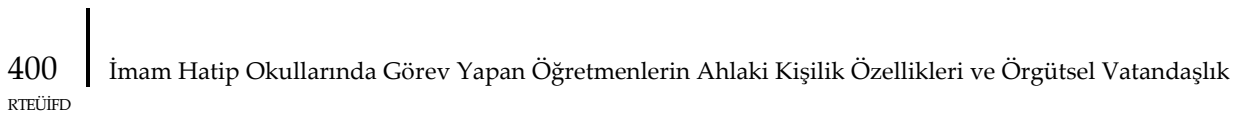

Tablo 5. Katılımcıların Ahlaki Kişilik Özellikleri ve Örgütsel Vatandaşlık Davranışları Arasındaki İlişki

\begin{tabular}{lccccccccc}
\hline Araştırma Değişkenleri & $\mathbf{N}$ & $\bar{X}$ & ss. & $\mathbf{1 .}$ & $\mathbf{2 .}$ & $\mathbf{3 .}$ & $\mathbf{4 .}$ & $\mathbf{5 .}$ & $\mathbf{6 .}$ \\
\hline $\begin{array}{l}\text { 1-Ahlaki Kişilik } \\
\text { 2-Örgütsel Vatandaşlık }\end{array}$ & 3642 & 3,73 & 0,30 & 1.00 & & & & \\
Davranışları & 3642 & 4,22 & 0,44 &, $537^{* *}$ & 1.00 & & & & \\
3-Yardımlaşma Boyutu & 3642 & 4,21 & 0,49 &, $457^{* *}$ &, $871^{* *}$ & 1.00 & & & \\
4-Centilmenlik Boyutu & 3642 & 4,34 & 0,63 &, $447^{* *}$ &, $724^{* *}$ &, $470^{* *}$ & 1.00 & & \\
5-Vicdanlllik Boyutu & 3642 & 4,43 & 0,58 &, $399^{* *}$ &, $739^{* *}$ &, $514^{* *}$ &, $450^{* *}$ & 1.00 & \\
6-Sivil Erdem Boyutu & 3642 & 3,92 & 0,63 &, $366^{* *}$ &, $759^{* *}$ &, $564^{* *}$ &, $400^{* *}$ &, $429^{* *}$ & 1.00 \\
\hline
\end{tabular}

Elde edilen bulgulara göre Tablo 5'te görüldüğü gibi öğretmenlerin ahlaki kişilik özellikleri ortalama puanları ile örgütsel vatandaşlık davranışları ortalama puanları arasında pozitif yönde orta düzeyde anlamlı bir ilişki belirlenmiştir $(r=0,537 ; p<0,001)$. Buna göre öğretmenlerin ahlaki kişilik özellikleri puanları arttıkça örgütsel vatandaşlık davranışları puanlarının da arttığı söylenebilir. Determinasyon katsayısı dikkate alındığında $\left(r^{2}=0,29\right)$ örgütsel vatandaşlık davranışlarındaki değişkenliğin yaklaşık \%29'unun ahlaki kişilik özellikleri ile açıklanacağı söylenebilir. Bununla birlikte öğretmenlerin ahlaki kişilik özellikleri ortalama puanı ile örgütsel vatandaşlık davranışları alt boyutları yardımlaşma $(\mathrm{r}=0,457 ; \mathrm{p}<0,001)$, centilmenlik $(\mathrm{r}=0,447$; $\mathrm{p}<0,001)$, vicdanlllık $(\mathrm{r}=0,399 ; \mathrm{p}<0,001)$, sivil erdem $(\mathrm{r}=0,366 ; \mathrm{p}<0,001)$, ortalama puanları arasında pozitif yönde orta düzeyde anlamlı bir ilişki belirlenmiştir. Bu bulgulara göre öğretmenlerin kişilik özelliklerinin örgütsel vatandaşlık davranışı sergileme eğilimlerini etkileyen önemli belirleyicilerden biri olduğu söylenebilir.

İlgili literatür incelendiğinde kişilik, ahlaki kişilik, etik liderlik ile örgütsel vatandaşlık davranışı arasında pozitif yönde bir ilişkinin varlığı pek çok araştırmada ortaya konulmuştur. ${ }^{62}$ Araştırma bulgularımızı, özellikle ahlaki kişilik ile örgütsel vatandaşlık davranışı arasındaki ilişkiyi inceleyen araştırma sonuçlarıyla ${ }^{63}$ karşılaştırdığımızda benzer sonuçlara ulaştığımızı söyleyebiliriz. McFerran vd. araştırmasında ahlaki kişilik ile örgütsel vatandaşlık davranışı arasındaki ilişkiyi $(\mathrm{r}=0,37 ; \mathrm{p}<0,001)$ olarak tespit ederken araştırmamızda ise iki değişken arasındaki ilişki $(r=0,54 ; p<0,001)$ olarak bulunmuştur.

62 Lou Fan vd., "Influence of Personality on Organizational Citizenship Behavior", International Journal of Education and Research 2/11 (2014), 225-239; Q. Yang - H. Wei, "The Impact of Ethical Leadership On Organizational Citizenship Behavior: The Moderating Role of Workplace Ostracism", Leadership \& Organization Development Journal 39/ (2017), 100-113.

63 Cohen - Morse, "Moral Character: What It Is and What It Does"; Brent McFerran vd., "How Personality and Moral Identity Relate to Individuals' Ethical Ideology". 


\section{SONUÇ VE ÖNERİLER}

Öğretmenlerin ahlaki kişilik özelliklerini okul ortamında sergilemelerine ilişkin görüşleri dikkate alındığında ahlaki kişilik ve alt boyutlarından elde ettikleri toplam puan ortalamalarının "yüksek düzeyde" olduğu, katılımcıların ahlaki kişilik özelliklerinin alt boyutlarından en fazla dürüstlük/alçak gönüllülük ve en az ise uyumluluk boyutlarında puan aldıkları tespit edilmiştir. Özellik temelli yaklaşımlar esas alındığında bir dizi genel yatkınlık/eğilim özelliklerinin ahlaki kişilik üzerinde etkileri olduğu söylenebilir. Yüksek sorumluluk, uyumluluk, dürüstlük/alçak gönüllülük ve en azından orta derecede yüksek deneyime açıklık gibi bazı yatkınlık özelliklerinin, yüksek ahlaki işleyişin göstergesi olan düşünce ve davranış kalıpları ile ilişkili olma eğilimi taşıdığı birçok araştırmacı tarafından dile getirilmiştir ${ }^{64}$. Bu bağlamda genel olarak, sorumluluk, dürüstlük/alçak gönüllülük ve uyumluluk boyutlarında yüksek düzeyde puan alan öğretmenlerin toplum yanlısı davranışlar sergileyebilecekleri; deneyime açıklık düzeyinde yüksek puan alan öğretmenlerin ise ilkeli ahlaki muhakeme eğilimlerine sahip olabilecekleri söylenebilir. Ayrıca öğretmenlerin birbirleriyle ve eğitimin diğer paydaşlarıyla olan ilişkilerinde ve kurumsal görevlerinde ahlaki kişilik boyutlarını sağlayacağı adil olma, yasalara saygılı olma, gösterişten uzak durma, kendilerini üstün görmeme, disiplinli, gayretli, çalışkan, iradeli, prensip sahibi, hoşgörülü ve sabırlı olma, yenilikçi, özgün, açık fikirli olma gibi avantajlardan yararlanabileceği ifade edilebilir.

Araştırma verilerine göre öğretmenlerin toplam örgütsel vatandaşlık alg1 düzeyleri "çok yüksek düzeyde" çıkmıştır. Örgütsel vatandaşlık davranışının alt boyutlarından en çok gösterilen vicdanlılıktır ve "çok yüksek düzeyde" algılanmıştır. Örgütsel vatandaşlık davranışının alt boyutlarından en az gösterilen ise sivil edemdir ve "yüksek düzeyde" algılanmıştır. Buna göre imam hatip okullarında görev yapan öğretmenlerin okullarının hedeflerine ulaşması için fedakârlık gösterme, karşılaştıkları birçok sıkıntıya katlanma ve resmi rol gereklerinin dışındaki eylemleri kapsayan ekstra rol davranışlarını gösterebilecekleri ve örgütsel vatandaşlık davranışlarıyla ilgili olarak olumlu görüşlere sahip oldukları sonucuna varabiliriz. Bu sonuca göre Din Öğretimi Genel Müdürlüğü, imam hatip okullarının misyon ve vizyonlarının gerçekleştirilmesinde okul müdürlerine ve öğretmenlere daha fazla inisiyatif imkânı tanıyabilir. Çünkü çalışanların sık sık örgütsel vatandaşlık davranışları sergilediği kurumlarda eş güdüm, iletişim ve çatışma yönetimine daha az kaynak sarf edilir. Bunun yerine, örgüt kaynakları daha üretken hedeflere yönlendirilir. ${ }^{65}$ Ayrıca bu tip davranışların yaygın olduğu örgütlerde müşfik, insancıl

65 Anit Somech - Ifat Ron, "Promoting Organizational Citizenship Behavior in Schools: The Impact of Individual and Organizational Characteristics", Educational Administration Quarterly 43/1 (2007), 38-66. 
ve destekleyici bir kurum atmosferi oluştuğu için ${ }^{66}$ bireysel ve örgütsel performans düzeyi yükselerek kurumsal amaçlara daha kolay ulaşılması sağlanmış olur.

Öğretmenlerin ahlaki kişilik özellikleri ile örgütsel vatandaşlık davranışları algı düzeyleri arasında pozitif yönde orta düzeyde anlamlı bir ilişki gözlemlenmiştir. Bu bağlamda öğretmenlerin kişilikleri hakkında elde edilen bilgiler daha sonraki kariyer planlama, ekip oluşturma ve kurumsal gelişimle ilgili diğer etkinlikler için kullanılabilir. Aynı zamanda ahlaki kişiliğin alt boyutlarının ölçülmesinde ve değerlendirilmesinde farklı kişilik envanterleri kullanılarak karşılaştırmalı araştırmalar yapılabileceği gibi ahlaki kişiliğin eğitim ortamında iletişim becerileri, kullanılan yöntem ve teknikler, iş karşıtı davranışlar, liderlik davranışları gibi değişkenler arasındaki ilişkileri inceleyen yeni araştırmalar yapılabilir.

$\mathrm{Bu}$ araştırma imam hatip okullarında yapılmıştır. Benzer bir araştırma Milli Eğitim Bakanlığına bağlı resmi ve özel farklı seviyelerdeki eğitim kurumlarında ve yükseköğretim düzeyindeki kurumlarda karşılaştırmalı olarak yapılabilir.

66 Nathan P. Podsakoff vd., "Individual- and organizational-level consequences of organizational citizenship behaviors: A meta-analysis.", Journal of Applied Psychology 94/1 (2009), 122-141. 


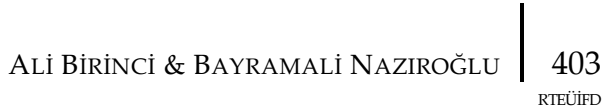

\section{KAYNAKÇA}

Ashton, Michael C. vd. "The HEXACO Honesty-Humility, Agreeableness, and Emotionality Factors: A Review of Research and Theory". Personality and Social Psychology Review 18/2 (2014), 139-152.

Bateman, Thomas S. - Organ, Dennis W. "Job Satisfaction and the Good Soldier: The Relationship Between Affect and Employee 'Citizenship.'” Academy of Management Journal 26/4 (1983), 587-595. https://doi.org/10.2307/255908

Blassi, Agusto. "Ahlaki Kişilik”. Değerler Eğitimi Ansiklopedisi. ed. Ronald J. Nuzzi vd. 35-36. İstanbul: Eğitim Danışmanlığı ve Araştırma Merkezi, 2018.

Büyüköztürk, Şener. Sosyal Bilimler İçin Veri Analizi El Kitabı. Ankara: Pegem Akademi Yayıncılık, 16. Basım, 2012.

Cervone, Daniel. "Personality Architecture: Within-Person Structures and Processes". Annual Review of Psychology 56/1 (2005), 423-452.

Chirumbolo, Antonio - Leone, Luigi. "Personality and Politics: The role of the HEXACO Model of Personality in Predicting Ideology and Voting." Personality and Individual Differences 49/1 (2010), 43-48.

Chuang, Pei-Ju - Chiu, Su-Fen. "When Moral Personality and Moral Ideology Meet Ethical Leadership: A Three-Way Interaction Model". Ethics \& Behavior 28/1 (2018), 45-69. https://doi.org/10.1080/10508422.2016.1229604

Cihan, Nazlı. “Okullarda Değerler Eğitimi ve Türkiye'deki Uygulamaya Bir Bakış”. Journal of Turkish Studies 9/2 (2014), 429-429.

Cohen, Taya R. - Morse, Lily. "Moral Character: What It Is and What It Does". Research in Organizational Behavior 34/ (2014), 43-61.

Cömert, Ezgi. Cinsiyete Göre Üniversite Öğrencilerinde Karanlık Üçlü: Hexaco Kişilik Özelliklerinin Yordayıcı Rolü. Mersin: Çağ Üniversitesi, Sosyal Bilimler Enstitüsü, Yüksek Lisans Tezi, 2018.

Dağlı, Emine. İlköğretim Okullarında Müdürlerin Kullandıkları Etkileme Taktiklerinin Öğretmenlerin Örgütsel Vatandaşlık Davranışları ve Okul Farkındalığı ile İlişkisi. Gaziantep: Gaziantep Üniversitesi, Eğitim Bilimleri Enstitü, Doktora Tezi, 2015.

Din Öğretimi Genel Müdürlüğü (DÖGM), “Din Öğretimi Portalı”. Erişim 01 Ekim 2021. http://dinogretimi.meb.gov.tr/Okullar.aspx 
\begin{tabular}{l|l}
404 \\
RTEÜIrFD
\end{tabular}

Doğan, Soner. - Yiğit, Yakup. “Öğreten Okulların Tamamlayıcısı: Öğrenen Okullar”. Elektronik Sosyal Bilimler Dergisi 14/53 (2015), 318-336.

Fan, Lou. vd. "Influence of Personality on Organizational Citizenship Behavior". International Journal of Education and Research 2/11 (2014), 225-239.

Güven, Murat. Örgütsel Bă̆gllık ve Örgütsel Vatandaşlık Davranışı Arasındaki İlişki. İstanbul:Marmara Üniversitesi, Sosyal Bilimler Enstitüsü, Yüksek Lisans Tezi, 2006.

Hacıahmetoğlu, Kübra Seynem. Kişilik Özelliklerinin Örgütsel Vatandaşlık Davranışı Üzerindeki Etkisi: Özel Bir Eğitim Kurumunda Bir Araştırma. İstanbul:Bahçeşehir Üniversitesi, Sosyal Bilimler Enstitüsü, Yüksek Lisans Tezi, 2020.

Howell,C. David. Statistical Methods for Psychology. Belmont, CA: Wadsworth, Cengage Learning, 2012.

İplik, N. Fatma. Örgütsel Vatandaşlık Davranışı. Ankara: Akademisyen Kitabevi, 2010.

İslamoğlu, Ahmet H - Alnıaçık, Ümit. Sosyal Bilimlerde Araştırma Yöntemleri. İstanbul: Beta Basım Yayım Dağıtım, 4. Basım, 2014.

Karagöz, Yalçın. SPSS ve AMOS Uygulamalı Nitel-Nicel-Karma Bilimsel Araştırma Yöntemleri ve Yayın Etiği. Ankara: Nobel Akademik Yayıncılık, 2017.

Kaynak, Selma. Öğretmenlerin Kişilik Özellikleri ve Örgütsel Vatandaşlık Davranışı. Afyon: Afyon Kocatepe Üniversitesi, Sosyal Bilimler Enstitüsü, Yüksek Lisans Tezi, 2007.

Lapsley, Daniel - Lasky, Benjamin. "Prototypic Moral Character". Identity 1/ (Ekim 2001), 345-363. https://doi.org/10.1207/S1532706XID0104_03

Lapsley, Daniel K. - Narvaez, Darcia. “A Social-Cognitive Approach to the Moral Personality." Moral Development, Self, and Identity. ed. Daniel K. Lapsley, Darcia Narvaez. 189-212. Mahwah, NJ: Lawrence Erlbaum Associates Publishers, 2004.

Lapsley, K. Daniel. “"Eğitimin Hedefi Olarak Ahlaki Öz Kimlik”. çev. Cengiz Şeker. Ahlak ve Karakter Eğitimi El Kitabı. ed. Larry P.Nucci - Darcia Narvaez. 33-56. İstanbul: Eğitim Danışmanlığı ve Araştırma Merkezi, 2019.

Lee, Kibeom - Ashton, Michael C. "Psychometric Properties of the HEXACO Personality Inventory". Multivariate Behavioral Research 39/2 (2004), 329-358.

Lee, Kibeom - Ashton, Michael C. The H Factor of Personality: Why Some People are Manipulative, Self-Entitled, Materialistic, and Exploitive-and Why It Matters for Everyone. Waterloo, ON: Wilfrid Laurier University Press, 2012.

Lorcu, Fatma. Örneklerle Veri Analizi SPSS Uygulamalı. Ankara: Detay Yayıncılık, 2005. 
McAbee, Samuel T. vd. "The HEXACO Model in Education and Work: Current Applications and Future Directions." Zeitschrift für Psychologie 227/3 (2019), 174185. https://doi.org/10.1027/2151-2604/a000376

McAdams, Dan P. “The Moral Personality". Personality, Identity, and Character: Explorations in Moral Psychology. ed. Darcia Narvaez, Daniel K. Lapsley. 11-29. New York, NY : Cambridge University Press, 2009.

McFerran, Brent vd. "How Personality and Moral Identity Relate to Individuals' Ethical Ideology". Business Ethics Quarterly 20/ (2010), 35-56.

Moorman, Robert H. "Relationship between Organizational Justice and Organizational Citizenship Behaviors: Do Fairness Perceptions Influence Employee Citizenship?" Journal of Applied Psychology 76/6 (1991), 845-855.

Mustafayeva, Lale. Sosyal Sorumluluk ile Örgütsel Vatandaşlık Davranışları ve Örgütsel Özdeşleşme Arasındaki İlişkiye Yönelik Bir Araştırma. Kütahya: Dumlupınar Üniversitesi, Sosyal Bilimler Enstitüsü, Yüksek Lisans Tezi, 2007.

Ones, S. Deniz vd. "Comprehensive Meta-Analysis of Integrity Test Validities: Findings and Implications for Personnel Selection and Theories of Job Performance." Journal of Applied Psychology 78/4 (1993), 679-703.

Organ, Dennis W. Organizational Citizenship Behavior: The Good Soldier Syndrome. Lexington, MA: Lexington Books, 1988.

Organ, Dennis W. “Organizational Citizenship Behavior: It's Construct Clean-Up Time". Human Performance 10/2 (1997), 85-97.

Podsakoff, Nathan P. vd. "Individual- and organizational-level consequences of organizational citizenship behaviors: A meta-analysis." Journal of Applied Psychology 94/1 (2009), 122-141. https://doi.org/10.1037/a0013079

Podsakoff, Philip M. vd. “Organizational Citizenship Behaviors: A Critical Review of the Theoretical and Empirical Literature and Suggestions for Future Research". Journal of Management 26/3 (2000), 513-563. https://doi.org/10.1177/014920630002600307

Polat, Soner. Ortaöğretim Öğretmenlerinin Örgütsel Adalet Algıları, Örgütsel Güven Düzeyleri ile Örgütsel Vatandaşlık Davranışları Arasındaki İlişki. Kocaeli: Kocaeli Üniversitesi, Sosyal Bilimler Enstitüsü, Doktora Tezi, 2007.

Santrock, W. John. A Topical Approach to Life-Span Development. New York: McGrawHill Education, 10. Basım, 2019. 
Sjahruddin, H. vd. "Personality Effect on Organizational Citizenship Behaviour (OCB): Trust in Manager and Organizational Commitment Mediator of Organizational Justice in Makassar City Hospitals (Indonesia". European Journal of Business and Management 5/9 (2013), 95-104.

Somech, Anit - Ron, Ifat. "Promoting Organizational Citizenship Behavior in Schools: The Impact of Individual and Organizational Characteristics". Educational Administration $\quad$ Quarterly $\quad 43 / 1 \quad$ (2007), 38-66. https://doi.org/10.1177/0013161X06291254

Somer, Oya.“Türkçe'de Kişilik Özelliği Tanımlayan Sıfatların Yapısı ve Beş Faktör Modeli". Türk Psikoloji Dergisi 13/42 (1998), 17-32.

Şen, H. Şenay. "Eğitim Açısından Toplumsal Değişme ve Yenileşme". Eğitim Bilimine Giriş. ed. Emin Karip. 163-180. Ankara: Pegem Akademi, 2009.

T.C. Milli Eğitim Bakanlığı (MEB), “T.C. Millî Eğitim Bakanlığı”. Erişim 08 Ekim 2021. https://2023vizyonu.meb.gov.tr/

Thielmann, Isabel vd. "On Measuring the Sixth Basic Personality Dimension: A Comparison Between HEXACO Honesty-Humility and Big Six HonestyPropriety". Assessment 24/8 (2017), 1024-1036.

Totan, Tarık. vd. “Öğretmen Adaylarının Mizaç Karakter ve Kimlik Özellikleri”. İnönü Üniversitesi Ĕ̆itim Fakültesi Dergisi 11/2 (2010), 19-43.

Ulu, Mustafa-Bulut, B. Meryem. “Üniversite Öğrencilerinin Kişilik Özelliklerinin Hexaco ile Ölçülmesi". Bilimname 34/ (2017), 443-463.

Walker, Lawrence J. "Moral Personality, Motivation, and Identity". Handbook of Moral Development. ed. Melanie Killen, Judith G. Smetana. 497-519. New York, NY: Psychology Press, 2. Basim, 2014.

Walker, Lawrence J. - Frimer, Jeremy A. "Moral Personality of Brave and Caring Exemplars." Journal of Personality and Social Psychology 93/5 (2007), 845-860.

Walker, Lawrence J. - Pitts, Russell C. "Naturalistic Conceptions of Moral Maturity." Developmental Psychology 34/3 (1998), 403-419.

Wasti, S. Arzu vd. "Six Turkish Personality Factors and the HEXACO Model of Personality Structure". Journal of Cross-Cultural Psychology 39/6 (2008), 665-684.

Yang, Q. - Wei, H. "The Impact of Ethical Leadership on Organizational Citizenship Behavior: The Moderating Role of Workplace Ostracism". Leadership $\mathcal{E}$ Organization Development Journal 39/ (2017), 100-113. 